\title{
THE 2011 OICHALIA (SW PELOPONNESE, GREECE) SEISMIC SWARM: GEOLOGICAL AND SEISMOLOGICAL EVIDENCE FOR E-W EXTENSION AND REACTIVATION OF THE NNW-SSE STRIKING SIAMO FAULT
}

\author{
Ganas A. ${ }^{1}$, Lekkas E. ${ }^{2}$, Kolligri M. ${ }^{1}$, Moshou A. ${ }^{1}$, Makropoulos K. ${ }^{1,2}$ \\ 1'Institute of Geodynamics, National Observatory of Athens, Greece, aganas@noa.gr \\ ${ }^{2}$ Department of Geology, University of Athens \\ Corresponding author, aganas@noa.gr
}

\begin{abstract}
The Upper Messinia basin (Peloponnese, Greece) hosted a seismic swarm during the second half of 2011 . The geological evidence (surface breaks striking $\mathrm{N} 160^{\circ} \mathrm{E}$ ), the seismological data (distribution of relocated earthquakes and T-axis orientation) and severe damage distribution are aligned along the eastern margin of the basin, so as they are attributed to reactivation of the bordering NNW-SSE normal fault. In particular, the rupture of the 14 August $2011 \mathrm{M}=4.8$ event is associated to the surface breaks inside the village Siamo. The length of the reactivated fault is estimated as $7 \pm 1 \mathrm{~km}$ based on the longest dimension (NW-SE) of the swarm epicentres (June to October 2011). The mode of rupture of the Siamo fault is probably related to a) the change in stress field orientation from south to north inside the basin (from E-W extension in the Siamo - Katsaro area to N-S extension in the north of Oichalia area) and/or b) to the occurrence of magmatic fluids due to the proximity of Messinia to the Hellenic subduction.
\end{abstract}

Keywords: earthquake swarm, normal faulting, hypoDD, Messinia, Greece

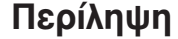

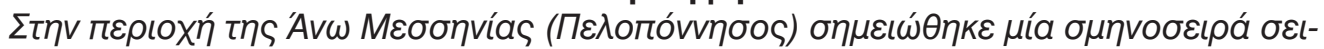

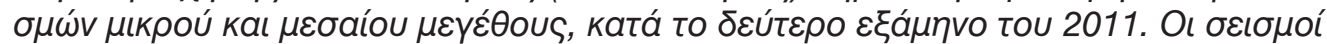

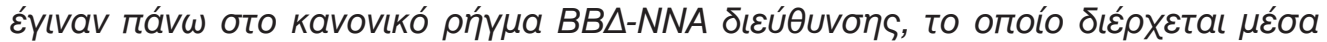

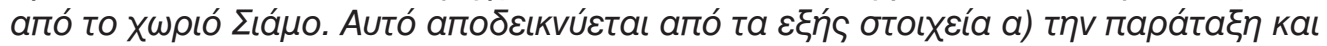

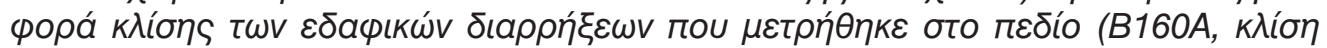

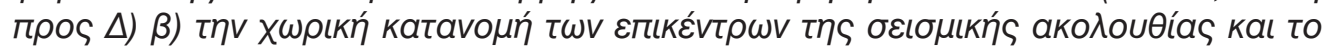

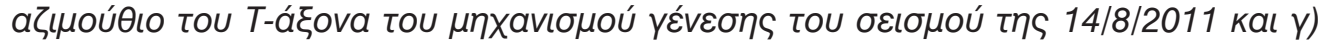

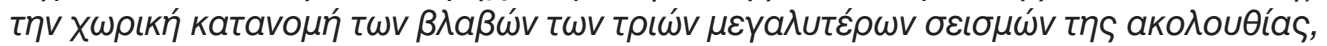

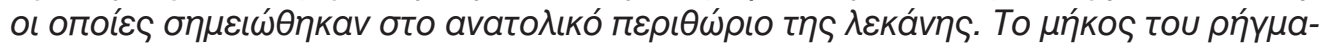

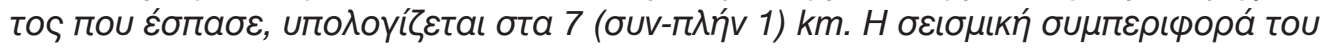

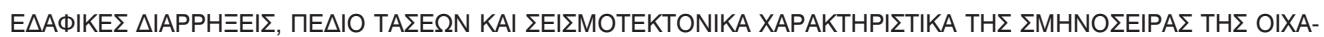
NIA $\Sigma(2011, A N \Omega$ ME $\Sigma \Sigma H N I A)$.

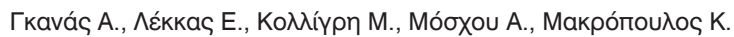




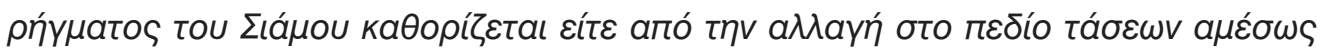

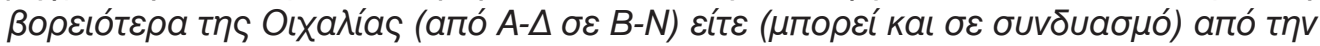

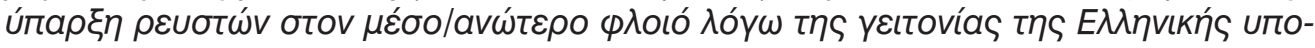

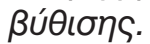

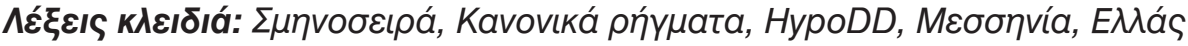

\section{Introduction}

Messinia (SW Peloponnese, Greece, Fig. 1) is one of the tectonically and seismically most active areas of the Hellenic arc, because of its proximity to the Hellenic trench where the African plate subducts beneath the Aegean microplate (Eurasia; Caputo et al., 1970; Papazachos and Comninakis, 1971; Hatzfeld et al., 1989, 1990; Papanikolaou et al., 2007). The convergent plate motion results in intense deformation of the crust and the release of stored elastic energy by seismic slip along large faults (e.g. Papazachos et al., 1991; Papoulia and Makris, 2004). A component of regional uplift is also present (Ganas and Parsons, 2009) because of the 3-5 times higher velocity of the overriding upper plate (Aegean) in comparison to the descending African plate.

Both historical and instrumental data show that earthquakes in SW Peloponnese are both strong and destructive. The most destructive ones are shallow events that are the result of elastic deformation of the upper (Aegean Plate), as well as of plate convergence along the shallow part of the Hellenic arc megathrust. The intermediate earthquakes are due to the deformation of the subducting African Plate, as it descends beneath Peloponnese. The last major event was the 14 February $2008 \mathrm{M}=6.7$ earthquake offshore Methoni (Roumelioti et al., 2009) where the shallow part of the megathrust ruptured in a sequence rich of aftershocks that lasted almost one year. The most recent, onshore, disas- trous earthquake was the 13 September 1986 event (Lyon-Caen et al., 1988) that occurred on a N-S striking, W-dipping normal fault near the city of Kalamata. The region of Upper Messinia displays a complex neotectonic structure without a potential for large earthquakes (i.e. $\mathrm{M}>6$, Papoulia and Makris, 2004). Previous moderate events include the 1 March 2004 00:36 UTC normal-slip event to the North of Kalamata (Pirli et al., 2007; NOA local magnitude is $M=5.0$; Fig. 2) and the 16 September 2001 02:00 UTC $M=5.1$ event to the northwest of Meligalas (Papoulia and Makris, 2004; see Fig. 1 for location, NOA local magnitude is $\mathrm{M}=5.2$ at $37.29^{\circ} \mathrm{N}, 21.83^{\circ} \mathrm{E}$, depth of $5 \mathrm{~km})$.

During the second half of 2011 a seismic swarm occurred inside the Upper Messinia basin (Fig. 2; Chouliaras et al., 2013). The main events were on August 14, 2011 (Moment Magnitude $M w=4.8$; Fig. 2), September 14, $2011(M w=4.6)$ and on October 10, $2011(\mathrm{Mw}=4.7)$. This paper presents a) an analysis of seismological data collected by NOA, and b) geological observations from field work conducted in the swarm area during October 2011. The main point of our findings was to identify the NNW-SSE striking, west-dipping plane as the $14 / 8 / 2011$ slip plane, whose rupture is associated to the surface breaks inside village Siamo. A second point is the spatial correlation of the June - October 2011 swarm occurrence to an area of nearly 90 degrees difference in crustal extension azimuth. 


\section{Geology}

The geology of Messinia mostly comprises sedimentary rocks of the alpine orogenesis (Figure 1; Fytrolakis, 1971; Mariolakos et al., 1994; Ladas et al., 2004; Pavlopoulos et al., 2010). The nappe sequence consists of a relatively autochthonous unit, the Tripolis unit, and an alloch- thonous one, the Pindos unit. The Tripolis unit consists of neritic carbonates and flysch, outcropping mostly at the western part of Messinia. The Pindos unit occupies mainly the eastern part Messinia forming a classic nappe, which has overthrusted Tripolis from east to west direction.

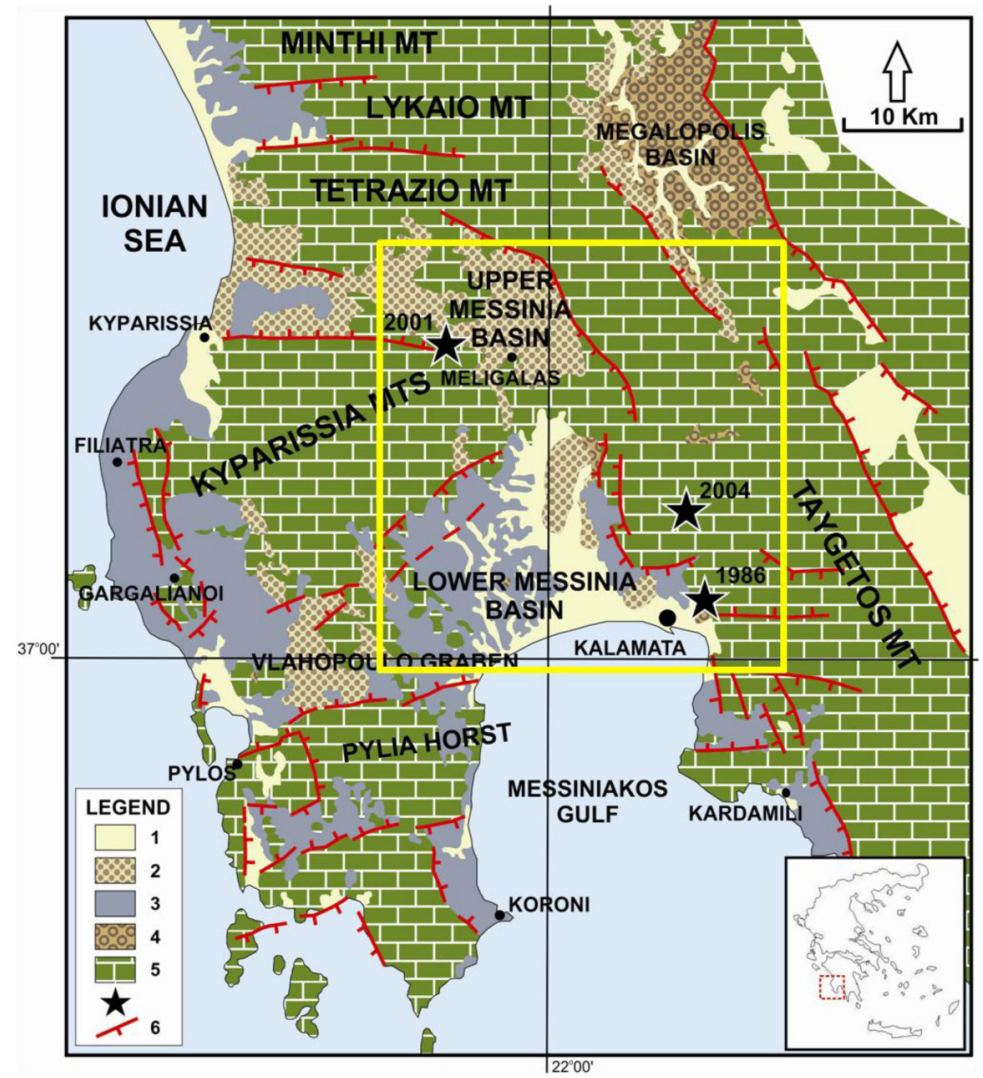

Fig. 1. Neotectonic map of Southwest Peloponnese (modified after Ladas et al., 2004). 1: Holocene deposits, 2: Neogene-Quaternary continental deposits, 3: Neogene-Quaternary marine deposits, 4: Lacustine deposits, 5: Pre-neogene basement (Alpine units \& Messinia conglomerates), 6: red lines with ticks represent active fault zones. Stars: Epicentres of moderate, onshore shallow earthquakes, on 2001 near Meligalas $M(N O A)=5.2$ and on 2004 near Kalamata $M(N O A)=5.0$. The 1986 shallow earthquake epicentre is also shown near Kalamata. Yellow square box shows extent of Fig. 2 and Fig. 5a. Location of map with respect to the Hellenic arc is shown in lower inset box.

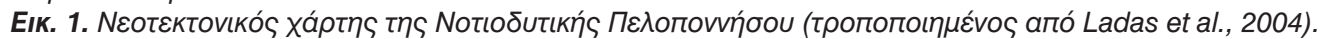

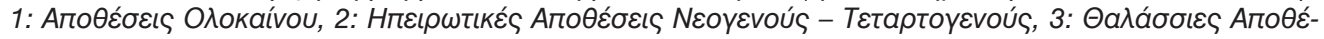

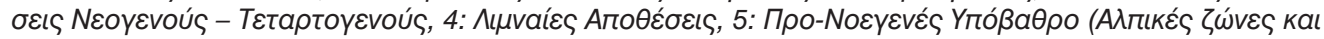

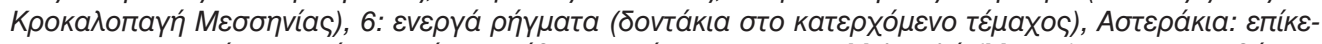

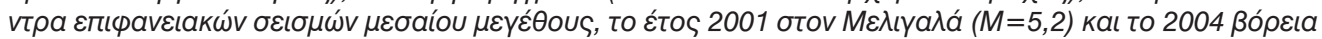

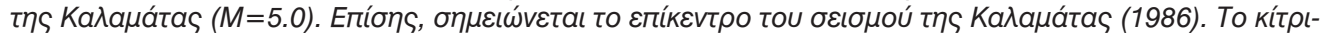

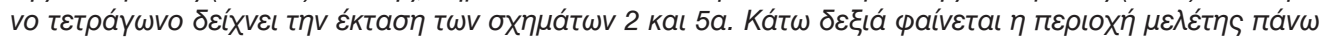

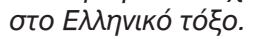


Pindos unit is represented with the Triassic clastic formation at the bottom of its stratigraphic column up to the Eocene flysch at the top. The whole unit is intensively folded and faulted, forming successive thrusts of Oligocene motion (Pavlopoulos et al., 2010), cut by neotectonic faults (post-Miocene) of normal kinematics. The post-alpine deposits can be distinguished into (a) marine, (b) terrestrial and (c) lacustrine formations. The marine deposits consist of marls, sandstones and conglomerates. They occur in all basins except in the land-locked ba- sin of Upper-Messinia (Fig. 1). Their total thickness differs from place to place reaching $200 \mathrm{~m}$ at a location near the city of Koroni, where the upper sequences of the marine deposits are of Early Pleistocene age or younger (Mariolakos et al., 2001). Early Pleistocene marine sedimentation is also reported at the adjacent areas of Filiatra and Lower Messinia basin by Marcopoulou-Diacantoni et al. (1989, 1991).

The neotectonic (post - Miocene) structure of Messinia is characterized by the presence of large grabens and horsts

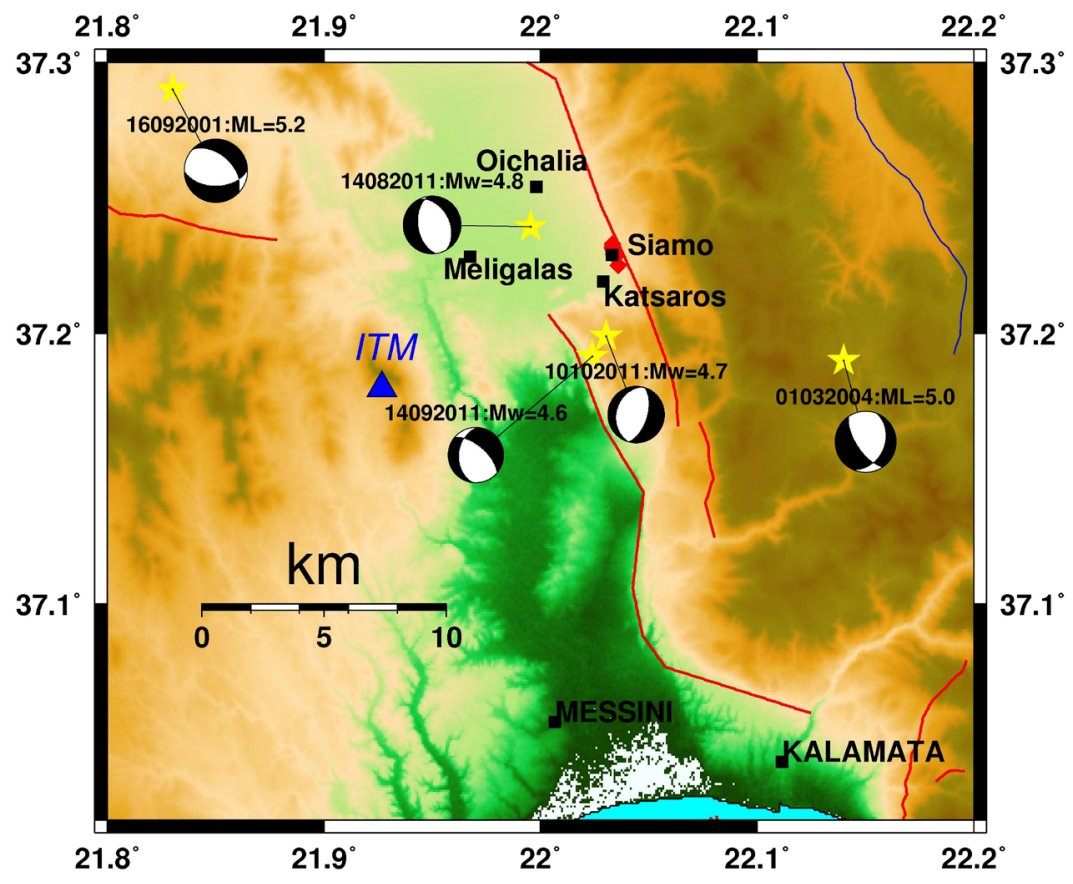

Fig. 2. Map of Messinia basins showing traces of major active faults (red lines) and focal plane solutions (beachballs; compressive quadrants in black) of the three main events of the 2011 seismic swarm, the 16 September 2001 ML(NOA) 5.2 event (focal plane solution by E. Sokos) and the 1 March 2004 ML(NOA) 5.0 event (USGS Moment tensor solution). Red rhombs near Siamo indicate the 14 August 2011 surface breaks. Blue triangle labeled ITM is the NOA broadband seismic station Ithomi.

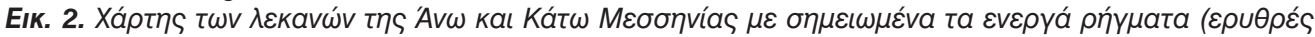

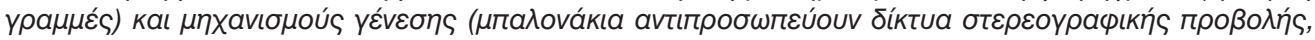

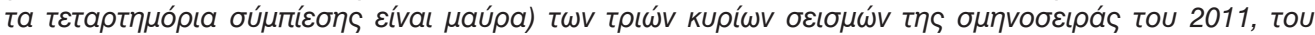

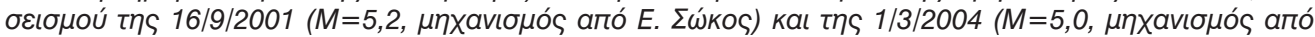

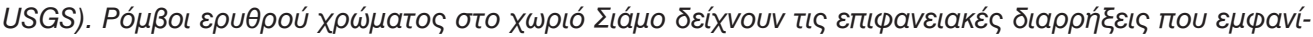

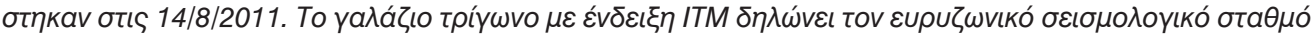

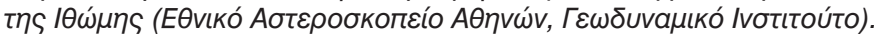


bounded by wide fault zones, striking both N-S and E-W (Fig. 1). The main structures are (a) the Taygetos Mt horst, (b) the Kalamata (Lower Messinia) graben c) The Kyparissia graben, (d) the Kyparrisia Mts. horst, (d) the Vlahopoulo graben and (e) the Pylia Mts horst. The pattern and growth of these neotectonic units is complicated because of regional uplift (Ganas and Parsons, 2009), crustal block rotation along horizontal axes (tilting) and normal fault development throughout Quaternary.

\section{Seismological Data Analysis}

The 2011 swarm started in April 2011 and escalated after June 2011 with the occurrence of small - moderate size events inside the basin of Upper Messinia (Fig. 2). On 14 August 2011, an $\mathrm{M}=4.8$, normal-slip event occurred near the town of Oichalia followed by hun- dreds of aftershocks (Fig. 2).

The epicentre of this event was relocated at 21.995 East, 37.239 North (see analysis below) with a depth of $6 \mathrm{~km}$ and a focal plane solution of $172^{\circ} / 50^{\circ} /-78^{\circ}$ (strike/dip/rake). A magnitude $M=4.6$ normal-slip event also occurred on 14 September 2011 (depth $5 \mathrm{~km}$ ) and finally, on 10 October 2011 one normal-slip event of $M=4.7$ occurred to the south of village Katsaros (Fig. 2; hypocentre depth $5 \mathrm{~km}$ ). The focal mechanisms of the main events and other events with $M \geq 4.0$ were determined by the MT method. The moment tensor inversion method used data (waveforms) of 10 broadband stations equipped with three-component seismometers, from the Hellenic Unified Seismological Network (HUSN). The source parameters (Tab. 1) were calculated using regional waveforms at epicentral distances less than $3^{\circ}$.

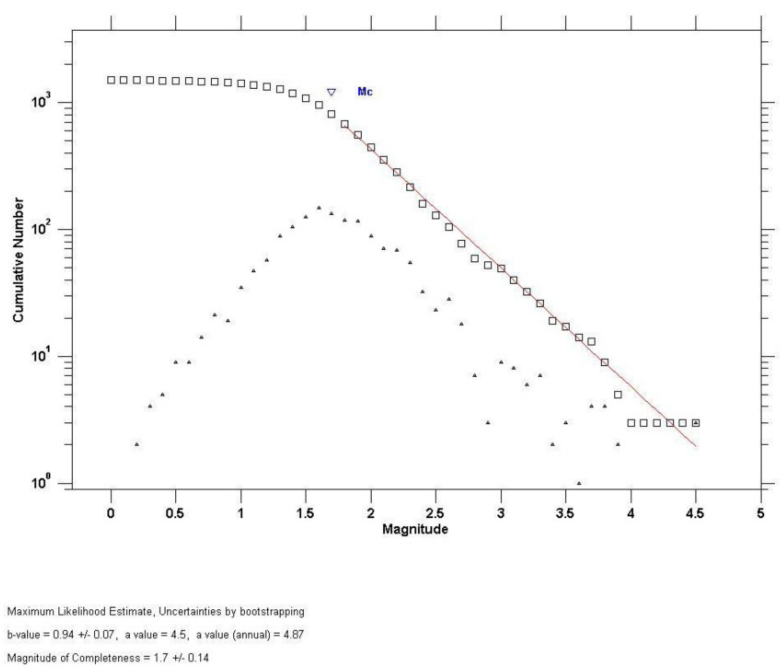

Fig. 3. Graph showing the magnitude distribution of the Oichalia 2011 swarm earthquakes (Gutenberg - Richter, 1944 relationship) with $b=0.94$ and $M c=1.7$. $b$-value is the slope of the cumulative frequencymagnitude distribution of earthquakes and Mc is completeness magnitude. The ZMAP software was used (Maximum Likelihood Estimate).

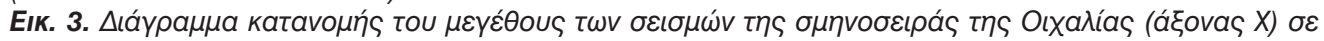

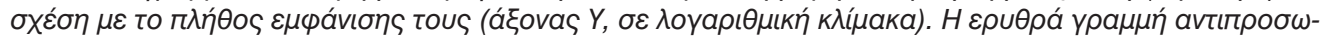

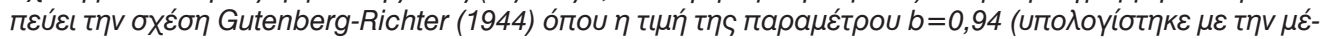

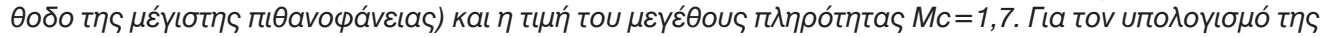

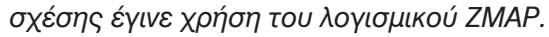


The preparation of the data includes the deconvolution of instrument response, followed by velocity integration to displacement and finally the horizontal components rotated to radial and transverse. Then the method uses the long period part of the signal to invert. Nodal plane 1 strike range is (Tab. 1) from $\mathrm{N} 168^{\circ} \mathrm{E}$ to $\mathrm{N} 195^{\circ} \mathrm{E}$, dip range is from $31^{\circ}$ to $50^{\circ}$ and rake angle range is from $-44^{\circ}$ to $-91^{\circ}$ (i.e. normal slip with a sinistral component). This NNW-SSE orientation of the nodal planes matches the geomorphic expression of the basin-bounding normal fault to the east of Oichalia (Fig. 2) and is a clear indication of an indirect association of seismicity with surface geology.

A statistical analysis of the seismic data from the NOA catalog (http://www.gein. noa.gr/en/seismicity/earthquake-catalogs) for the period June to October
2011 indicated a b-value of 0.94 with a magnitude of completeness of $\mathrm{Mc}=1.7$ (Fig. 3; Mc is the minimum magnitude in which the catalog is complete, Wiemer and Wyss, 2000). The b-value is a measure of the relative number of small to large earthquakes that occur in a given area in a given time period and it is the slope of the frequency-magnitude distribution of earthquakes (Fig. 3; Gutenberg and Richter, 1944, $\log N=a-b M)$. The b-value of 0.94 is close to average (1.0) for active tectonic areas (Frolich and Davis, 1993).

All earthquakes were relocated using the HYPOINVERSE (Y2000 version) and the HYPODD (Double Difference) algorithms, in succession. Phase data were available from the permanent seismic network of NOA in HYPO71 (Lee and Lahr, 1972) format. For the region of our interest, we relocated 881 earth-
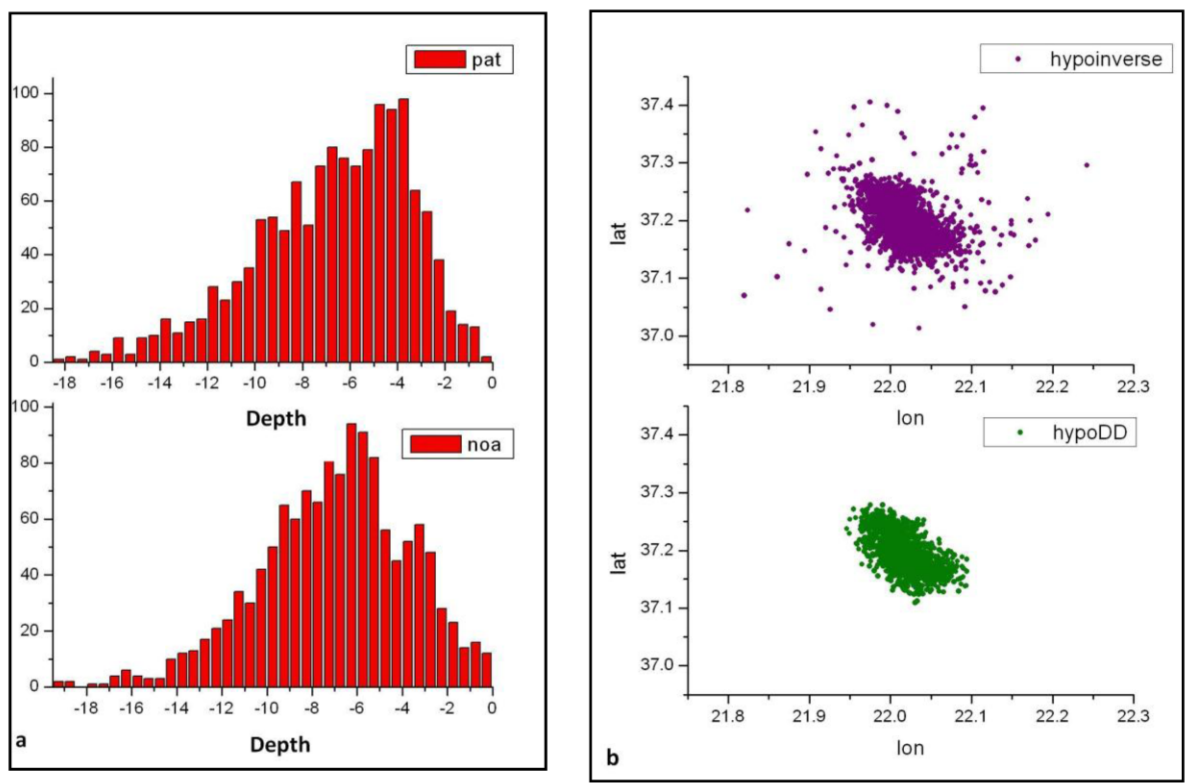

Fig. 4. a) Comparison of 1-D velocity model behavior regarding the depth distribution of the swarm hypocentres. $Y$-axis is number of events. The models are presented in Tab. $2 b$ ) Comparison of epicentre distribution after HypoDD relocation.

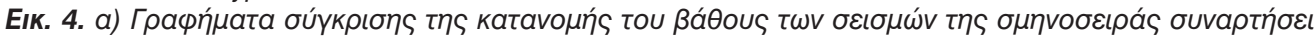

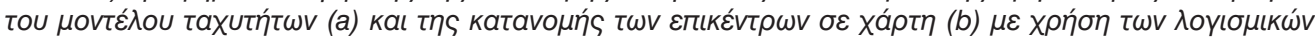
Hypoinverse \& HypoDD. 
quakes, including the three main seismic events, during the period 10/6/2011 - 13/10/2011 (Fig. 4). The parameters of these earthquakes were initially determined by the algorithm HYPO71, using the 1-D NOA velocity model (Tab. 2). Next step was the relocation of all seismic events with the algorithm HYPOINVERSE. During this procedure, no data were rejected. The main characteristic of HYPOINVERSE, that we exploited, was that every phase $(P$ and $S$ ) is assigned a weight code that indicates the weight that the phase carries to the final solution. At this stage it was found that the so-called Patras velocity model behaved better in the depth estimation of hypocentres (Fig. 4a) as it fits better the information provided by the focal plane solutions of the 3 main events $(6 \mathrm{~km}$ and $5 \mathrm{~km}$, respectively, a similar result was found by Ganas et al., 2009 in the case of Kato Achaia earthquake of 2008). Therefore, we suggest that the hypocentres are distributed more towards the shallower depths than at deeper ones. The mean errors of the relocation procedure are the following: solution RMS $0.52 \mathrm{~s}$, epicentre horizontal error 1.78 $\mathrm{km}$ and vertical error $4.16 \mathrm{~km}$. The errors are reasonable given that we used phase data from the unified seismological network (HUSN) of Greece available at the NOA parametric database. Then, we continued with relocation of the seismic events using the HYPODD algorithm (Double Difference earthquake algorithm). The double-difference technique allows the use of any combination of ordinary phase picks from earthquake catalogs and/or high precision differential travel times from phase correction
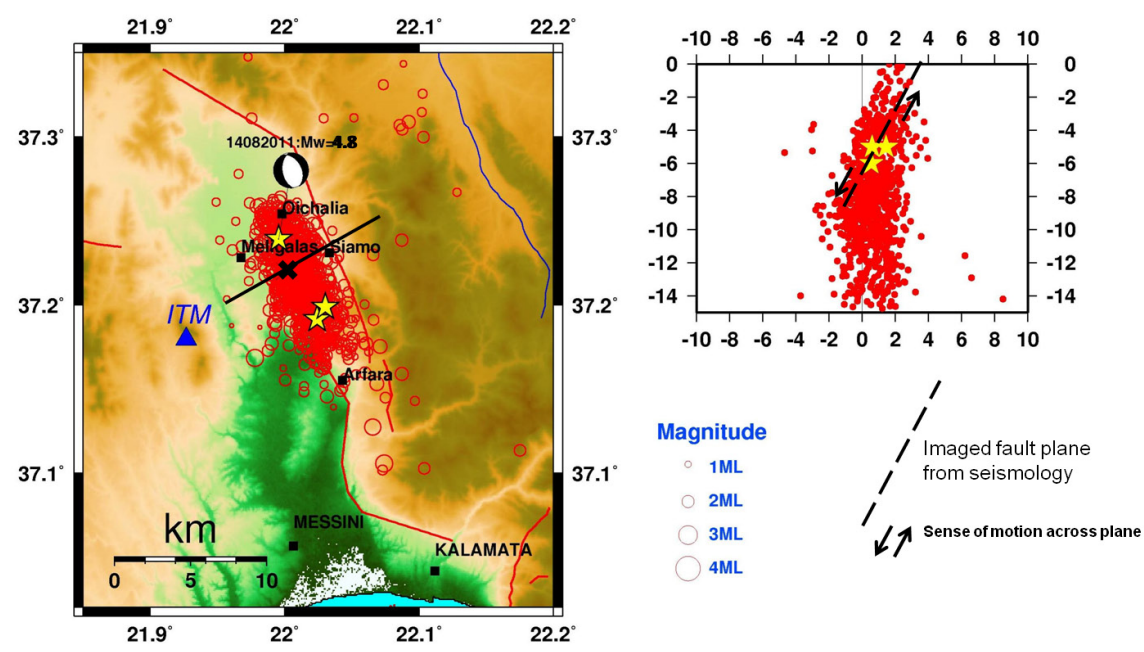

Fig. 5. (left) Map of central Messinia region showing relocated epicenters of the Oichalia earthquake sequence (period 10/6/2011-13/10/2011; 881 events) and (right) $N 65^{\circ} \mathrm{E}$ cross section. Stars denote the epicentres of the three main events. A high-angle, west-dipping fault plane (dashed line) is defined through the aftershock cloud which matches the nodal plane 1 of the 14/8/2011 solution (see Tab. 1). X symbol on the left (map) is point zero of the vertical section (right).

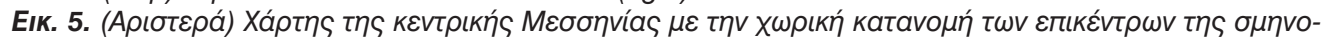

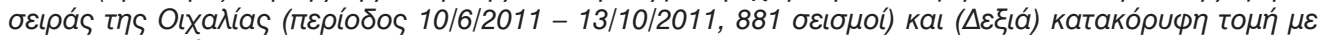

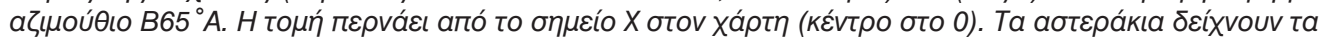

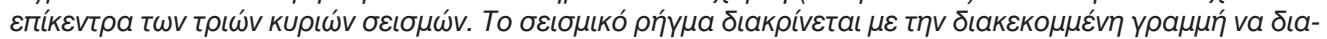

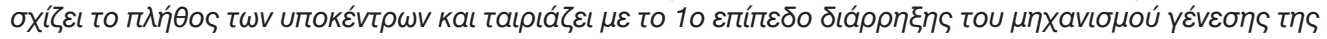

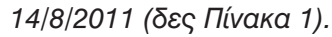


of P- and/or S- waves (cross-correlation data). We only have phase picks available from the earthquake catalogs of the National Observatory of Athens. For the area of our interest, we have chosen the conjugate gradients method (LSQR, Paige \& Saunders, 1982) and the 1-D velocity model of Tselentis and Zahradnik (2000; referred as Patras model; Tab. 2). Fig. 4b shows the comparison of epicentre distribution using Hypoinverse and HypoDD assuming a "Patras" velocity model. The length of the reactivated fault is estimated at $7( \pm 1) \mathrm{km}$ on the basis of the longest dimension (NW$\mathrm{SE})$ of the seismic swarm during the period June to October 2011. After 10 October 2011 seismicity spread further to the south reaching the village Arfara (Fig. 5). A vertical cross section through the swarm cloud shows that many relocated hypocentres are nearly aligned along a high-angle, west-dipping fault (see black, dashed line in Fig. 5) while the focal mechanism of the 14/8/2011 earthquake is also compatible with this interpretation because of its dip-slip kinematics. The strike of the longest swarm dimension is between $\mathrm{N} 160^{\circ} \mathrm{E}-\mathrm{N} 170^{\circ} \mathrm{E}$ and the strike of the cross-section is $\mathrm{N} 65^{\circ} \mathrm{E}$, i.e. $\pm 5^{\circ}$ from orthogonal. In the cross section it is imaged a west-dipping fault with a dip angle of about $60^{\circ}$ which is close to the one determined by MT inversion for the $14 / 8 / 2011$ event $\left(50^{\circ}\right.$, see Table 1).

\section{Geological and Seismotectonic observations}

Most of 2011 swarm events occurred in the hangingwall of the large, NNW-SSE striking normal fault zone that bounds the Upper Messinia basin to the east (Fig. 1 and Fig. 2).

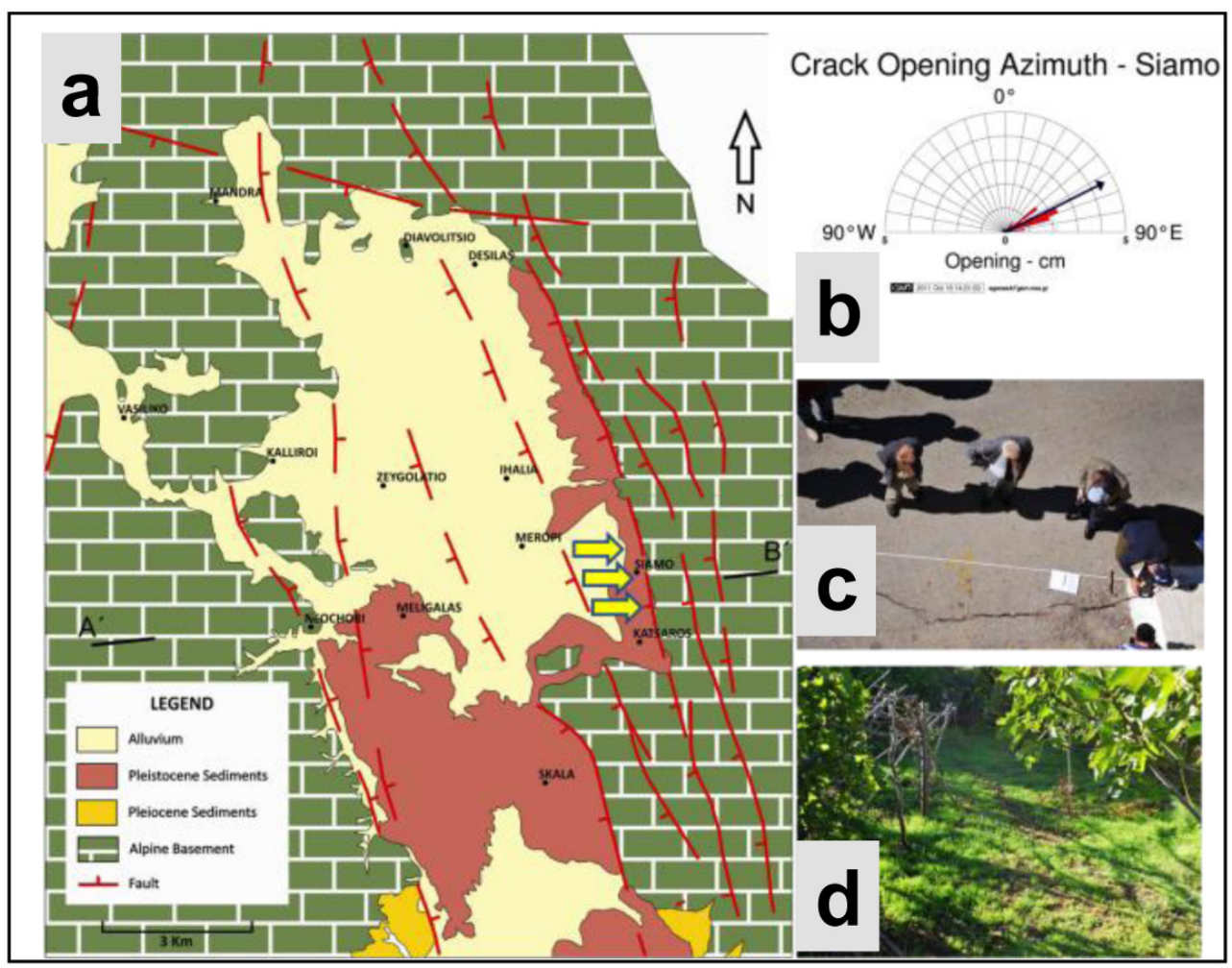




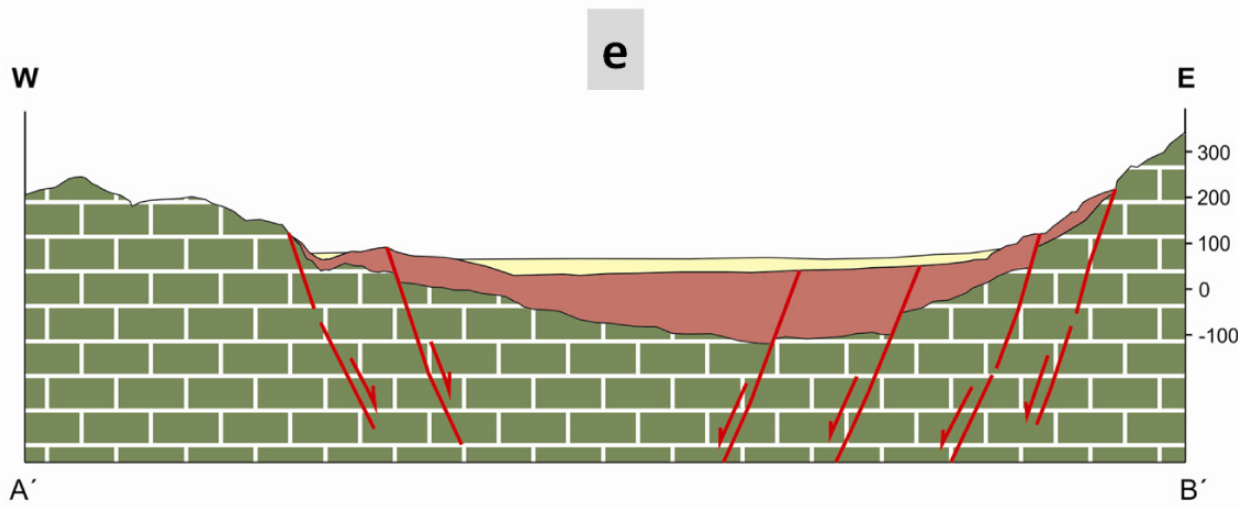

Fig. 6. a) Simplified geological map of Upper Messinia basin showing active faults (red lines), location of surface breaks (yellow arrows) and important towns and villages b) rose diagram of geological data collected in village Siamo on October 12, 2011 c) top-view of surface cracks along Siamo's main road d) same as c but $100 \mathrm{~m}$ to the northwest, e) schematic cross-section A'B' (see 6a for location) approximately normal to regional geological structure.

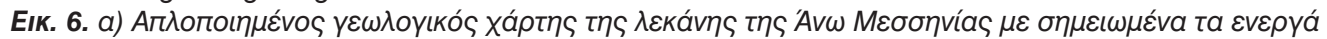

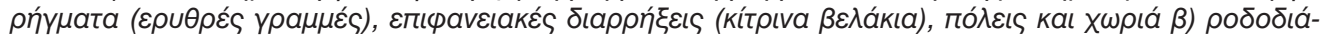

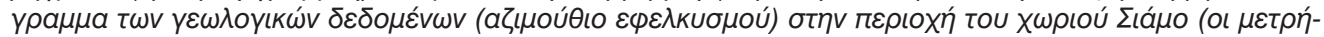

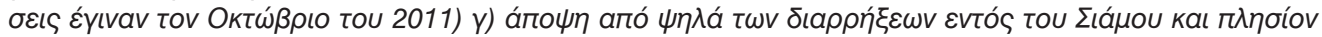

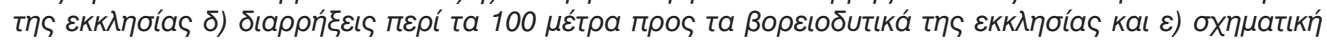

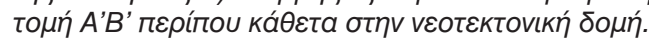

During October 2011 we conducted field reconnaissance studies and we mapped surface cracks in the area of village Siamo (Fig. 6a), aligned in a NNW-SSE direction. The breaks were formed immediately after the 14 August 2011, 01:05 UTC $(M=4.8)$ event according to local reports and were discontinuous, enechelon and about $500 \mathrm{~m}$ long, extending both to the north and to the south of the village. The average strike of the surface breaks were $\mathrm{N} 160^{\circ} \mathrm{E} \pm 5^{\circ}$. We found no cracks inside village Katsaro despite the intensity of earthquake shaking as reported by the locals. The breaks inside the village Siamo were measured for their attitude (Fig. 6b, 6c; strike, aperture, throw, opening azimuth). Most breaks exhibit minor throw $(0.1-3 \mathrm{~cm})$ to the west. In Fig. $6 \mathrm{~b}$ we plotted a rose diagram of the field data containing pairs of opening azimuth, aperture (in centimeters), using a 10-degree bin sector width, on a grid going out to radius $=5$ $\mathrm{cm}$ in steps of $1 \mathrm{~cm}$. The mean opening azimuth of the surface breaks is $\mathrm{N} 63^{\circ} \mathrm{E}$. This direction is approximately normal to the mean orientation of the aftershock cloud $\left(\mathrm{N} 160^{\circ} \mathrm{E}-\mathrm{N} 170^{\circ} \mathrm{E}\right)$ and approximately normal to the imaged normal fault (Fig. 5). The geological evidence (i.e. $\mathrm{N} 63^{\circ} \mathrm{E}$ ) is also in close agreement with the T-axis orientation (azimuth $73^{\circ}$, plunge $4^{\circ}$ ) of the moment tensor solution for the 14 August 2011 event $172^{\circ} / 50^{\circ} /$ $78^{\circ}$ (strike/dip/rake; Tab. 1).

\section{Discussion}

A first important observation is the kinematics and orientation of the seismic faulting. Both seismological (Fig. 5) and geological data (Fig. 6) point out that the reactivated structure is one of the major normal faults of Upper Messinia, crossing the village Siamo. Of particular importance is the strike of the seismic fault $\left(\mathrm{N} 160^{\circ} \mathrm{E}-\mathrm{N} 170^{\circ} \mathrm{E}\right)$ as this area is well known for the change in extension direc- 
tion of present-day deformation (Mariolakos et al., 2001; Papoulia and Makris, 2004; see Fig. 1 for a map of major normal faults in south - central Peloponnese). The severe damage distribution (communicated to us by the local authorities) is also aligned along the eastern margin of the Upper Messinia basin (villages Siamo and Katsaros; Fig. 2), so as they are attributed to seismic motion along the bordering NNW-SSE normal fault crossing Siamo.

A second important observation is the release of elastic, stored energy by a seismic swarm and not by the occurrence of a single moderate event. We recovered local newspaper articles from 1917 reporting swarm-type seismicity events felt by the Oichalia population, that we confirmed by looking at NOA Bulletins. Although we have no adequate information on this fault's seismic history (from palaioseismology or historical earthquake catalogs) we believe that the mode of rupture of the Siamo fault is mostly by the episodic occurrence of seismic swarms or by moderate events not exceeding $M=5.5$. This upper magnitude threshold is derived from the longest dimension of the swarm (7 $\pm 1 \mathrm{~km}$ ) by using the Papazachos et al. (2004) global formula: $\log L=0.50 \mathrm{M}$ - $1.86(\sigma=0.13)$. This behavior may be characteristic for this area of Peloponnese as it is well-known that the seismic potential of the normal faults to the south of Oichalia towards Kalamata town, as well as to neighbouring areas like Megalopoli, Messini, Kyparissia (see Fig. 1 for location) etc is in the range of $6<M<6.5$. This notable difference in the seismic potential is due to one of the following: a) it may be related to the change in the orientation of the stress field immediately to the North of Oichalia - Siamo villages (Fig. 2; from E-W extension to N-S exten- sion; the 16/9/2001 focal plane solution indicates an E-W striking normal fault, E. Sokos personal communication), as suggested by the E-W bounding faults of mountains Tetrazio and Lykaio (Fig. 1) and a pattern change in regional strain as described in previous works (e.g. Papazachos et al., 1998 for seismological data and Kokkalas et al., 2006 for neotectonic data), therefore, the Oichalia area comprises a transitional stress field region ( $\sigma 3$ may rotate by $70-90^{\circ}$ ) where strain cannot accumulate along large normal faults and where earthquake ruptures may be moderate in size (magnitudes not exceeding $M=5.5$ ) and/or $b$ ) may be the occurrence of fluids at high levels in crust (10 - $20 \mathrm{~km}$ depth) due to the proximity of Messinia to the Hellenic subduction. Fluids and gases may originate from a magmatic source below the crust of Messinia as the Nubia Plate subducts beneath Peloponnese. Such fluids may reduce normal stress levels along existent normal faults, thus, modulating elastic strain energy release by frequent small and moderate events, usually characterized by a hypocentre migration in time and space (e.g. Hayashi and Morita, 2003; Hainzl, 2004). We cannot differentiate at this point between the mechanisms (rheology vs. strain) and to suggest an explanation why swarms repeatedly exist in the Oichalia area, as we need more seismological data from local networks and seismic tomography images to look for possible fluids.

\section{Conclusions}

1. The rupture of the 14 August 2011 $M=4.8$ event is associated to the surface breaks inside village Siamo. The breaks were discontinuous, en-echelon and about $500 \mathrm{~m}$ long. All breaks are oriented $\mathrm{N} 160^{\circ} \mathrm{E}$ (NNW-SSE) and exhibit minor throw $(0.1-3 \mathrm{~cm})$ to the 
west.

2. The severe damage distribution is aligned along the eastern margin of the Upper Messinia basin, so as they are attributed to the reactivation of the bordering NNW-SSE normal fault.

3. The opening azimuth of the surface breaks is $\mathrm{N} 63^{\circ} \mathrm{E}$. This orientation of strain is close to the T-axis azimuth $\left(\mathrm{N} 73^{\circ} \mathrm{E}\right)$ of the 14 August 2011 $\mathrm{M}=4.8$ event.
4. The length of the reactivated fault is estimated to $7 \pm 1 \mathrm{~km}$ on the basis of the longest dimension (NNW-SSE) of the seismic swarm during the period June to 10 October 10, 2011.

5 . The mode of rupture of the Oichalia seismic fault is related to a) the change in stress field orientation, immediately to the North of Oichalia town (Fig. 1; from E-W extension to $\mathrm{N}-\mathrm{S}$ extension) as this area compris-

\begin{tabular}{|c|c|c|c|c|c|c|c|c|c|c|c|c|}
\hline Date & Time & Latitude & Longitude & Magnitude & Depth & Strike 1 & Dip 1 & Rake 1 & Strike 2 & Dip 2 & Rake 2 & $\mathbf{M}_{0}$ \\
\hline $14 / 08 / 2011$ & 01:05:01.90 & 37.2527 & 22.0047 & 4.8 & 6 & 172 & 50 & -78 & 334 & 40 & -104 & $1.33 \mathrm{E}+23$ \\
\hline $22 / 08 / 2011$ & $08: 50: 46.74$ & 37.2432 & 22.0117 & 4.1 & 4 & 168 & 41 & -83 & 338 & 48 & -97 & $1.66 \mathrm{E}+22$ \\
\hline $23 / 08 / 2011$ & $05: 22: 23.09$ & 372,270 & 22.0192 & 4.0 & 9 & 182 & 48 & -62 & 324 & 48 & -118 & $9.42 \mathrm{E}+21$ \\
\hline $14 / 09 / 2011$ & $03: 35: 27.60$ & 37.1898 & 22.0453 & 4.6 & 5 & 184 & 40 & -44 & 310 & 63 & -122 & $8.03 \mathrm{E}+22$ \\
\hline $10 / 10 / 2011$ & $01: 20: 56.91$ & 37.2145 & 22.0433 & 4.3 & 8 & 174 & 50 & -62 & 324 & 68 & -102 & $2.76 \mathrm{E}+22$ \\
\hline $10 / 10 / 2011$ & 19:07 & 37.1888 & 22.0442 & 4.7 & 5 & 195 & 31 & -91 & 340 & 60 & -90 & $1.39 \mathrm{E}+23$ \\
\hline $10 / 10 / 2011$ & $04: 49: 43.25$ & 37.2155 & 22.0238 & 4.3 & 5 & 178 & 50 & -80 & 346 & 65 & -95 & $0.325 \mathrm{E}+23$ \\
\hline $11 / 10 / 2011$ & 01:10:08.33 & 37.1908 & 22.0073 & 4.0 & 4 & 176 & 32 & -62 & 324 & 61 & -107 & $1.26 \mathrm{E}+22$ \\
\hline $14 / 11 / 2011$ & $18: 28: 08: 90$ & 37.2315 & 21.995 & 4.1 & 4 & 177 & 37 & -56 & 317 & 59 & -113 & $1.67 \mathrm{E}+22$ \\
\hline
\end{tabular}

Tab. 1. Focal mechanisms of nine (9) $M \geq 4.0$ earthquakes of the Oichalia seismic swarm determined by moment tensor inversion.

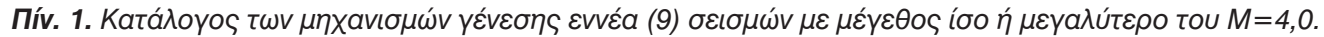

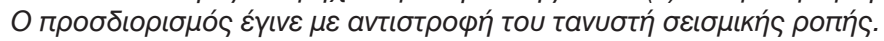

\begin{tabular}{|c|c|c|c|}
\hline \multicolumn{2}{|c|}{ NOA Velocity Model } & Depth & $\mathrm{V}_{\mathrm{p}}$ \\
\hline Depth & $\mathrm{V}_{\mathrm{p}}$ & $(\mathrm{km})$ & $(\mathrm{km} / \mathrm{s})$ \\
\hline$(\mathrm{km})$ & $(\mathrm{km} / \mathrm{s})$ & 0.0 & 5.7 \\
\hline 0.0 & 5.3 & 5.0 & 6.0 \\
\hline 4.0 & 6.0 & 18.0 & 6.4 \\
\hline 33.0 & 6.9 & 39.0 & 7.9 \\
\hline 45.0 & 7.9 & & \\
\hline 85.0 & 8.3 & & \\
\hline
\end{tabular}

Tab. 2.1-D Velocity models used in relocation

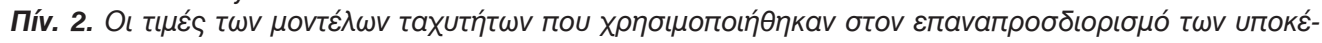

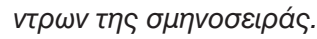


es a transitional stress field region in SW Peloponnese where earthquake ruptures may be moderate in size (magnitudes not exceeding $\mathrm{M}=5.5$ ) and/or $b$ ) to the occurrence of fluids at high levels in the crust of Messinia due to the proximity of this area to the Hellenic Subduction.

\section{Acknowledgements}

We thank Riccardo Caputo and one anonymous reviewer for comments and suggestions. We thank our colleagues E. Sokos and I. Kassaras for discussions and the NOA analysis group for phase picking. We also thank Alexandra Zampetaki and Asimina Antonarakou for editorial assistance. We are indebted to the inhabitants of Siamo and the local authorities and in particular Mr. P. Alevras, and $\mathrm{Ph}$. Bamis for assistance and support. Figs 2, 3 and 5 were constructed by use of GMT and ZMAP software (Wiemer, 2001). This research was supported by project XENIOS (General Secretariat of Research and Technology, Greece) and EPPO (www.oasp.gr) funds.

\section{References}

Caputo, M., Panza. G.F., Postpischl, D., 1970. Deep structure of the Mediterranean basin. Journal of Geophysical Research, 75 (26), 4919-4923.

Chouliaras, G., Drakatos, G., Pavlou, K., Makropoulos, K. 2013. Stress distribution and seismicity patterns of the 2011 seismic swarm in the Messinia basin, (South-Western Peloponnesus), Greece. Nat. Hazards Earth Syst. Sci., 13, 45-51, doi:10.5194/ nhess-13-45-2013.

Frolich, C., Davis, S., 1993. Teleseismic b-values: or much ado about 1.0. Journal of Geophysical Research, 98, 631-644.
Fytrolakis, N., 1971. Geological studies in Pylia province (Messinia, Peloponessus, Greece), Ph.D. Thesis. Ann. Geol. Des Pays Helln., 23, 57-122, (in Greek with German abstract).

Ganas A., Parsons, T., 2009. 3-D model of Hellenic Arc deformation and origin of the Cretan uplift. Journal of Geophysical Research, 114, doi:10.1029/2008JB005599.

Ganas, A., Serpelloni, E., Drakatos, G., Kolligri, M., Adamis, I., Tsimi, Ch., Batsi, E., 2009. The Mw 6.4 SWAchaia (Western Greece) Earthquake of 8 June 2008: Seismological, Field, GPS Observations, and Stress Modeling. Journal of Earthquake Engineering, 13:8,1101 - 1124 .

Gutenberg, B., Richter, C.F., 1944. Frequency of earthquakes in California. Bull. Seismol. Soc. Am., 34, 185188.

Hainzl, S., 2004. Seismicity patterns of earthquake swarms due to fluid intrusion and stress triggering. Geophysical Journal International, 159, 1090-1096 http://dx.doi.org/10.1111/j.1365246X.2004.02463.X

Hatzfeld, D., Pedotti, G., Hatzidimitriou, P., Panagiotopoulos, D., Scordilis, M., Drakopoulos, J., Makropoulos, K.C., Delibasis, N., Latoussakis, J., Baskoutas, J., Frogneux, M., 1989. The Hellenic subduction beneath the Peloponessus: first results of a microearthquake study. Earth and Planet. Sci. Lett., 93, 283-291.

Hatzfeld, D., Pedotti, G., Hatzidimitriou, P., Makropoulos, K.C., 1990. The strain pattern in the western Hellenic arc deduced from a microearthquake survey. Geophys. J. Int., 101, 181-202.

Hayashi, Y, Morita, Y., 2003. An image 
of a magma intrusion process inferred from precise hypocentral migrations of the earthquake swarm east of the Izu Peninsula. Geophysical Journal International, 153, 159174.

Kokkalas, S., Xypolias, P., Koukouvelas, I., Doutsos, T. 2006. Post-Collisional Contractional and Extensional Deformation in the Aegean region. In: Dilek, Y., Pavlides, S. (Eds). Post Collisional Tectonics \& Magmatism in the Mediterranean Region and Asia. Geological Society of America Special Paper, 97-123

Ladas, I., Mariolakos, I., Fountoulis, I., 2004. Neotectonic Deformation of Eastern Pylia (SW Peloponnese, Greece). Bulletin of the Geological Society of Greece. 36, 1652-1661.

Lee, W. H. K., Lahr, J. C., 1972. HYP071: A computer program for determining hypocenter, magnitude, and first motion pattern of local earthquakes. Open File Report, U. S. Geological Survey, $100 \mathrm{pp}$.

Lyon-Caen, H., et al., 1988. The 1986 Kalamata (South-Peloponnesus) Earthquake - Detailed study of a normal-fault, evidences for East-West extension in the Hellenic Arc. J. Geophys. Res., 93(B12), pp. 1496715000.

Mariolakos, I., Fountoulis, I., Marcopoulou-Diacantoni, A., Mirkou, M.R., 1994. Some remarks on the kinematic evolution of Messinia Province (SW Peloponnesus, Greece) during the Pleistocene based on Neotectonic Stratigraphic and Paleoecological observations. Munster. Forsch. Geol. Palaont., 76, 371-380, Munster.

Mariolakos I., Fountoulis, I., Ladas, I., 2001. Paleogeographic evolution of SW Peloponnesus during Quater- nary. Bull. Geol. Soc. Greece, 34, 37-45, (in Greek with English abstract).

Marcopoulou-Diakantoni, A., Mirkou, M.R., Mariolakos, I., Logos, E., Lozios, S., Fountoulis, I., 1989. Stratigraphic observations at the post-alpine sediments of the Thouria - Ano Amphia area (SW Peloponnese), and their neotectonic interpretation. Bull. Geol. Soc. Greece, 23, 275-295, (in Greek with English abstract).

Marcopoulou-Diacantoni, A., Mirkou, M.R., Mariolakos, I., Fountoulis, I., 1991. Stratigraphic and paleogeographic observations at the post-alpine sediments of the Filiatra area (SW Peloponnese), and their neotectonic interpretation. Bull. Geol. Soc. Greece, 25, 593-608, (in Greek with English abstract).

Papanikolaou, D., Fountoulis, I., Metaxas, Ch., 2007. Active faults, deformation rates and Quaternary paleogeography at Kyparissiakos Gulf (SW Greece) deduced from onshore and offshore data. Quaternary International, 171-172, 14-30.

Papazachos, B.C., Scordilis, E. M., Panagiotopoulos, D.G., Papazachos, C.B., Karakaisis, G.F., 2004. Global relations between seismic fault parameters and moment magnitude of earthquakes. Bulletin of the Geological Society of Greece, 36, 14821489.

Papazachos, B.C., Papadimitriou, E.E., Kiratzi, A.A., Papazachos, C.B. Louvari, E.K., 1998. Fault plane solutions in the Aegean sea and the surrounding area and their tectonic implications. Bolletino di Geofisica Teorica ed Applicata, 39, 199-218.

Papazachos, B., Kiratzi, A., Papadimitriou, E. 1991. Regional focal mechanisms for earthquakes in the Aege- 
an Area. Pure Appl. Geophys, 136, 407-420.

Papazachos, B. C., Comninakis, P. E., 1971. Geophysical and tectonic features of the Aegean arc. J. Geophys. Res., 76, 8517-8533.

Papoulia, J., Makris, J., 2004. Microseismicity and active deformation of Messinia, SW Greece. Journal of Seismology, 8, 439-451.

Pavlopoulos, A., Kamperis, E., Sotiropoulos, S., Triantaphyllou, M., 2010. Tectonosedimentary significance of the Messinia conglomerates (SW Peloponnese, Greece). Bulletin of the Geological Society of Greece. Proceedings of the 12th International Congress Patras, May, 2010, 715725.

Pirli, M., Voulgaris, N., Chira, A., Makropoulos, K., 2007. The March 2004 Kalamata seismic sequence: a case of efficient seismicity monitoring in the area of Peloponnese, southern Greece, by the Tripoli Seismic Array. J. Seismology, 11, 59-72.

Roumelioti, Z., Benetatos, Ch., Kiratzi, A., 2009. The 14 February 2008 earthquake (M6.7) sequence offshore south Peloponnese (Greece): Source models of the three strongest events. Tectonophysics, 471, 3-4, 272-284.

Tselentis, G.-A., Zahradnik, J., 2000. The Athens earthquake of 7 September 1999. Bull. Seismol. Soc. Am. 90:1143-1160.

Wiemer, S., 2001. A software package to analyse seismicity: ZMAP. Seismological Research Letters, 72(2), 374-383.

Wiemer, S., Wyss, M., 2000. Minimum magnitude of completeness in earthquake catalogs: examples from Alaska, the western United States, and Japan. Bull. Seismol. Soc. Am., 90 (4), 859-869. 